\title{
Human biography - the arena of democratic negotiations
}

\section{KEYWORDS}

democracy, human being, biography, community

\begin{abstract}
Grażyna Teusz, Human biography - the arena of democratic negotiations. Culture - Society - Education no. 2(18) 2020, Poznań 2020, pp. 213-218, Adam Mickiewicz University Press. ISSN 2300-0422. DOI 10.14746/ kse.2020.18.8.2.

The subject-matter of this paper is an attempt to outline the type of relationship that exists between democracy and the autonomous and responsible individual as a necessary pre-condition for a real and genuine community. The author's reflections are focused around the idea that only a conscious, inner-directed and mature individual can guarantee a solid foundation for the rules and practice of democracy and that human biography is the actual arena of democratic negotiations constantly being undertaken.
\end{abstract}

Democracy has never had good press. Even though it has been loved and fervently defended, it has always had problems with theory. Since the beginning of political thought, the argumentation "against" has always prevailed over the argumentation "for". Everyone will find it easy to recall something from the long list of objections. For example, that the fundamental concept of equality for this system is, delicately speaking, non-empirical, that the assumption about the majority being more often right than wrong is a hardly plausible hypothesis, or that it is really hard to believe that mechanisms underlying a collective decision can have anything to do with reason. This list could be continued for a long time. Well, it has been agreed anyway that there is no better idea (Karłowicz, 2017: 172). 
If we accept a statement about the theoretical difficulties of democracy, what should we say about practical signs and methods of its functioning, about forms of its institutional and social incarnations that often reveal their problematic and weak character? Paradoxically, however, the stronger the tensions arising in the field of the democratic praxis that turn it into an element of unpredictable and difficult processes and reactions and the larger the extent to which the democratic spirit becomes eroded and weakened, the higher the awareness of the importance and meaning of democratic values and the stronger the attachment to democratic principles. The answer to the question that appears on such occasions - how to save democracy - seems to be obvious on the first impulse of the mind and heart: by cultivating principles that are important for the community and organise its life in social practice.

It seems, however, that the point lies deeper, that the original remedy for this situation should be sought in activities and measures aimed at reinforcing the individual so that he/she would achieve such a degree of internal autonomy that will make him/her an inner-directed and responsible individual and citizen. In other words, the biography of an individual human being is the basic "area" and "environment" in which the condition of democracy is set. It is the individual biography that becomes the fundamental arena of democratic negotiations a kind of agora on which efforts and attempts constantly resumed by the individual find expression, aiming at the achievement of inner freedom, self-steering and the ability to make creative decisions and to assume responsibility for the form and quality of his/her being. The individual biography, as some kind of existential pact constantly remaining in statu nascendi, a sincere conversation with oneself, suspended between poles of confidence and doubt, hope and scepticism, between reasons of the mind and passions, a persistent and relentless dialogue with the ambiguous and ambivalent world and a reflexive effort to add value to one's own experiences, is a specific attempt to agree upon and construct, on a microscale and in the space of contradictory and sometimes almost mutually exclusive arguments, some superior meaning and sense that finally determines the choice made by the individual and his/her attachment to specific principles. However, as Władysław Stróżewski notices, this choice and these principles constitute themselves on the basis of

[...] a more primary experience: the experience of a specific power within me that I can use in this or another way: make use of its existence or not and, by using it, direct it towards certain goals. Things become complicated: the original alternative refers not to the object of choice, but to my own attitude: it expresses itself in the opposition: I can - I cannot and, further, I want - I do not want (1992: 50-51). 
Within the scope of the biographic project, the image of the Self forms and a subjective individual way of thinking about oneself and one's own identity, and the understanding of the surrounding world and of the character of social interactions develops. The unique, inherently human skill and ability to situate one's own personal experience, on the one hand, in the most inner perspective (ad intra) and, on the other hand, in the perspective of ad extra - potential references towards others comes to the fore. Both vectors intersect in the individual horizon and confront themselves in the space of acts of reasoning and thinking, in the sphere of subjectively grounded feeling, individual sensitivity and evaluation. In this way, the individual Self becomes a specific, particular space for dialogue and the negotiation of multiple meanings and senses, a kind of 'dynamic structure consisting of many autonomous subjective positions' (Roszkowska, 2011: 64).

It can be said that the biographical range of the individual existence, being some kind of microbiography, is a 'network of subtle dependencies' remaining in the process of continuous negotiation and internal dialogue (Demetrio, 2000: 147). These dependencies find expression in the process of constantly resumed negotiational dialogue that should lead to the achievement of mature freedom by the individual along with responsibility for decisions and actions being undertaken. Only such free and responsible individuals can create a true community. In order to be able to create a community, we must create first ourselves and our personal modus of being with our whole being. It is a sine qua non condition, a feedback and the most important dimension constituting the form of "us" as a community.

To create oneself within the scope of one's own biography, which is perceived as the arena of constant negotiations, is to ask about the freedom of choice and decision and about the possibility of crossing the borders and what they contain. However, it is not only a question of the purely technical translocation process, but primarily of looking or justifications and reasons for this transgression. The human being begins to understand whom he/she could be and whom he/she could become to the extent to which he/she is himself/herself - that is, a self-conscious individual. In the process of internal dialogue, a specific sort of soliloqium, he/she achieves his/her own way of existence that opens up to relations of belonging and reciprocity towards another human being and towards others.

In the process of negotiations with various needs, desires and rights and with moral aspects of life being conducted by the individual within the space of one's own biography, he/she grows up to understand that, as Roger Scruton writes:

[...] society is a common heritage for which we learn to restrict our desires and to perceive our place in reality as a link of the constant chain of giving and taking and to understand that we do not have any right to destroy the goods inherited by us. This is because there 
exists a line of obligation between us and those who have given us what we have, and the prolongation of this line is an expression of our care about the future. We consider the future of our community not through the calculation of costs and profits, but more specifically; namely, we perceive ourselves as heirs of benefits that we are obliged to pass on further (2016: 45).

Referring later to Edmund Burke, Scruton notices that he believed that the relationships on which society is based - the ones that create its democratic ethos of functioning - can be built only from below, through face-to-face interactions. It is in the family, in clubs and association, at school, at work, in the church, in the team, in the regiment and at university that people learn to interact with others as free individuals who take responsibility for their own actions and are accountable to others (Scruton, 2016: 46). This grassroots development of the social dimension of life, arising from inherent human needs, becomes represented in the individual biography, in answers being obtained on the plane of personal experiences to questions of crucial importance from the perspective of human dignity and the timeless desire for a good and happy life, with the attitude of responsibility and trust on the one hand and with the attitude of temperance and sui generis fundamental restriction of one's own egoism on the other hand. Only in terms of behaviours and ways of living in which the human being confronts his/her own Self, is he/she able to make a personal, rationally motivated choice and is he/she ready to fulfil his own way of living in a community with and for others.

Thomas Hobbes formulated the following paramount idea of the social contract: 'there [is] no obligation on any man which arises not from some act of his own' (Hobbes, 2009: 303). It implies that the essence of obligations, rules, principles and standards present in social space is preceded by and made conditional upon an internal act negotiated in the free process of subjective dialogue. We could ask if this is really so? The answer seems simple and clear on the level of condition: this is what should be, but more complex on the level of empiricism and the facts. If this is not so, all turbulences taking place in democratic systems that lead to its negation and rejection in their most extreme form find their explanation exactly here. The democratic spirit should be upheld by a free individual that is able to manage his/her own life independently that treats himself/herself and others with respect. This individual, for whom his/her own and others' personal freedom should be the highest value and a sort of limes, bears moral responsibility for which values he/he will choose to implement with the use of this freedom. The truly free society is a community of responsible people. 
The issue of the human being as an individual entity perceived in the context of his/her communal existence as co-existing with and for others is always ultimately decided in democracy. The democratic reality is an invitation to go a certain way; it is sui generis a game, a game of individual freedoms, a game of choice between various possibilities, options and values. It also summons us to assume a specific way of living and opens some kind of space that is entered by an individual entity whose understanding of concrete good and a happy life stimulates the will to act and mobilises creative powers. In this way, the human being seems to participate in the process of special movement and is ready to make certain sacrifices, sometimes even suffer, for the complete self-fulfilment of his/her own being. However, he is also ready to impose self-limitations on his own claims, to "suspend" them in the name of solidarity and empathy.

Why does this happen? In the name of what reasons and principles, is he/she able to do this? This happens because he feels a conscious and autonomous individual - a citizen who adheres to the principle of reciprocity based on the recognition of rights and claims of other people so that they could also express and fulfil their rights and claims. As Piotr Augustyniak notices:

An authentically awakened society is not just a society awakened by energies penetrating them, but a society that is able to control such energies and guide them in a sovereign way. But this calls for the recognition of these powers and their critical evaluation. And this is where we reach the heart of the matter: this kind of collective consciousness is possible only when a society consists of individuals who have achieved empowerment in their individual life. Only such individuals are not only engaged in action, but they do so as a result of their own reflection and, consequently, conscious individual decisions. Thus, social awakening is authentic only when it is based on individual consciousness, attitude and activity that is usually called civil. An awakened society is a society of free and sovereign individuals - entities (2019: 32-33).

However, this is also based on the forming supra-individual principle that

[...] the collective self-consciousness of the entire society is characterised by concern for the common good. Citizenship is a specific world-view and disposition of the civil society that arises from the participation of individuals in its collective self-consciousness. Citizenship produces in a sense of attachment to society as a whole, which manifests itself in decisions and actions aimed at the protection and multiplication of the good of the entire society. Citizenship is a cognitive and normative attitude and a corresponding model of action; it is an attitude where the personality of the individual consciously allows him/her to participate in the collective personality that restricts and affects his/her decisions and actions. Citizenship is the acceptance of the obligation to act (at least to some extent) for the common good at the time of making decisions concerning contradictory interests or ideals. It imposes an obligation to consider the consequences of individual actions for the 
common good or society as a whole. Collective self-consciousness - the awareness that others participate with me in the same "us" contains also a normative requirement - obligation - of solidarity and the resulting mutual obligation of all people participating in it as members of the given society (Shils, 1994: 11-12).

This brings forth an important principle of mutual care for each other, a fundamental rule specifying the co-existence of free and responsible individuals that can be summarised to the deeply realised belief that we exist not only for ourselves, but also, maybe even primarily, with and for others both in the world and in society.

Let us conclude our reflections with words of Ralf Dahrendorf, who notices:

There is no doubt that political democracy and market economy are cold projects. They are civilisational inventions of enlightened minds and populations, but they do not make the heart beat faster - in fact, they should not. They are problem-solving mechanisms created in order to enable a change of tastes, policy or even leaders without bloodshed and unnecessary suffering. They are wonderful inventions as such and, not without a reason, they are highly appreciated. But they are not "home"; they do not give an identity or a sense of belonging to the human being. In this sense, they leave him/her behind the door, out in the cold, without shelter. Democracy and market economy are important, but not all-important. And there is a consideration of even larger importance. It seems that mechanisms of open society cannot be maintained if people do not know where they belong (1996: 9).

The knowledge where they belong and what results from this is something that they gain in the intra-individual negotiation process whose arena (agora) is their own mind and their own biography.

\section{Bibliography}

Augustyniak P. (2019), Wyspiański. Burzenie polskiego kościoła. Studium o „Wyzwoleniu”, Kraków.

Dahrendorf R. (1996), Wolność a więzi społeczne. Uwagi o strukturze pewnej argumentacji, in: Społeczeństwo liberalne. Rozmowy w Castel Gandolfo, przygotował i przedmową opatrzył K. Michalski, Kraków.

Demetrio D. (2000), Autobiografia. Terapeutyczny wymiar pisania o sobie, Kraków.

Hobbes T. (2009), Lewiatan, trans. C. Znamierowski, Warszawa.

Karłowicz D. (2017), Polska jako Jason Bourne, Warszawa.

Roszkowska M. (2011), Negocjowanie znaczeń $w$ dialogach wewnętrznych $z$ wyobrażonymi rozmówcami, in: Psychologia narracyjna. Tożsamość, dialogowość, pogranicza, eds. E. Dryll, A. Cierpka, Warszawa.

Scruton R. (2016), Jak być konserwatystą?, trans. T. Bieroń, Poznań.

Shils E. (1994), Co to jest społeczeństwo obywatelskie?, in: Europa i społeczeństwo obywatelskie. Rozmowy w Castel Gandolfo, przygotował i przedmową opatrzył K. Michalski, Kraków.

Stróżewski W. (1992), W kręgu wartości, Kraków. 